\title{
Parents matter: How supportive parenting influences the behaviours of youth, Maharashtra
}

International Institute for Population Sciences (IIPS)

Follow this and additional works at: https://knowledgecommons.popcouncil.org/departments_sbsr-pgy

Part of the Demography, Population, and Ecology Commons, Family, Life Course, and Society Commons, Gender and Sexuality Commons, International Public Health Commons, Medicine and Health Commons, and the Sociology of Culture Commons How does access to this work benefit you? Let us know!

\section{Recommended Citation}

International Institute for Population Sciences (IIPS). 2008. "Parents matter: How supportive parenting influences the behaviours of youth, Maharashtra," Youth in India: Situation and Needs Policy Brief no. 4. Mumbai: IIPS. 


\section{Parents matter: how supportive parenting influences the behaviours of youth, Maharashtra}

\begin{abstract}
GLOBALLY, MANY HAVE ACKNOWLEDGED THE IMPORTANT ROLE THAT parents play in shaping young people's health and personal development. ${ }^{\mathrm{b}} \mathrm{cd}$ e In India too, policies and programmes have increasingly recognised the need to actively engage parents in enabling adolescents to make safe and healthy transitions to adulthood. For example, the National Adolescent Reproductive and Sexual Health Strategy has noted the need for efforts to help key stakeholders, including parents, to understand and respond to adolescent needs. ${ }^{f}$ The design of appropriate strategies to engage parents is, however, hampered by the paucity of evidence available in India. Little is known, for example, about the socialisation of daughters and sons, the extent to which socialisation practices differ for daughters and sons, and the extent to and ways in which parents communicate sensitive matters to their adolescent children. Similarly, research is limited that sheds light on the role of socialisation patterns and parental interaction in influencing young people's schooling outcomes, decision-making ability, selfefficacy, gender role attitudes, civic participation or ability to exercise informed and safe choices in sexual and reproductive matters.
\end{abstract}

For the first time, data are available at the state level that shed light on socialisation and parent-youth interaction patterns from both the perspectives of young men and women and of parents of young people. This brief describes the relationships reported by youth and by parents, and underscores the extent to which socialisation patterns and the nature of interaction with parents play a key role in influencing young people's lives.

\begin{abstract}
The study
Data are drawn from the Youth in India: Situation and Needs study, a sub-nationally representative study undertaken for the first time in India of key transitions experienced by young people in six states of India. The study included a representative survey of young people in both rural and urban settings. Respondents included unmarried women and men and married women aged 15-24 and, in view of the paucity of married men in these ages, married men aged 15-29. The study also included in-depth interviews with mothers and fathers of young people.
\end{abstract}

In Maharashtra, the study was conducted in 2005-06. A total of 7,570 married and unmarried young women and men were interviewed in the survey. These included 1,947 married young women, 2,541 unmarried young women, 1,065 married young men and 2,017 unmarried young men. Additionally, in-depth interviews were held with 72 mothers and fathers of young people. This brief is based on findings obtained from unmarried youth and parents of young people.

The survey inquired about several aspects of parent-youth relationships. Controlling behaviour was measured by whether parents would be angry if youth participated in various social activities, ranging from socialising with same-sex and opposite sex friends, to becoming a member of a social group, to having a love marriage. Communication was measured by whether parents and youth had discussed a number of topics, ranging from the nonsensitive (schooling, friends) to the sensitive (romantic relationships, body changes and sexual/reproductive matters). Also asked was the

\footnotetext{
a Kumi-Kyereme, A., K. Awusabo-Asare, A. Biddlecom et al. 2007. Influence of social connectedness, communication and monitoring on adolescent sexual activity in Ghana, African Journal of Reproductive Health 11(3): 133-147.

b Hollander, D. 2007. Program for fathers helps them talk to young sons about sex and HIV risk, Perspectives on Sexual and Reproductive Health 39(4): 248-249.

Lederman, R.P., W. Chan and C. Roberts-Gray. 2004. Sexual risk attitudes and intentions of youth aged 12-14 years: survey comparisons of parent-teen prevention and control groups, Behavioural Medicine 29(4): 155-163.

d Ryan, S., K. Franzetta, J. Manlove et al. 2007. Adolescents' discussions about contraception or STDs with partners before first sex, Perspectives on Sexual and Reproductive Health 39(3): 149-157.

${ }^{e}$ Aspy, C.B., S.K. Vesely, R.F. Oman et al. 2007. Parental communication and youth sexual behaviour, Journal of Adolescence 30(3):449-466.

${ }^{\mathrm{f}}$ Ministry of Health and Family Welfare. 2006. Implementation Guide on RCH II: Adolescent Reproductive Sexual Health Strategy for State and District Programme Managers. New Delhi: Government of India.
} 
extent to which parents brought up daughters differently from sons, that is, allowed them less freedom of movement and expected more housework from them than their sons.

\section{Socialisation experiences}

Findings highlight that even in the same family, boys and girls were socialised differently. For example, $84 \%$ of young men reported that they had more freedom to go out than their sisters or female cousins and 39\% of young women reported that they had less freedom to go out than their brothers or male cousins. Likewise, $83 \%$ of young men reported that they were expected to do less housework than their sisters or female cousins and $44 \%$ of young women reported that they were expected to do more housework than their brothers or male cousins.

Findings confirm considerable parental control of youth friendships and social activities. They also suggest that parents were considerably more likely to disapprove of youth activities conducted with members of the opposite sex than with same-sex peers. For example, $88-89 \%$ of young women and $88 \%$ of young men perceived that their parents would disapprove if they opted for a love marriage. Over half of young men reported that both their father and their mother would disapprove if they talked to someone of the opposite sex; among young women, in contrast, three-fifths and two-thirds reported that their father and mother, respectively, would disapprove of any social interaction with members of the opposite sex. In contrast, few (3-7\%) young women and men reported that their mother or father would be angry if they interacted socially with same-sex friends. reported expecting their father's disapproval for joining a club or mandal.

Insights from in-depth interviews with parents also confirm the gendered nature of socialisation patterns. For example, almost all parents with both daughters and sons who were interviewed in-depth reported that their sons were allowed greater freedom of movement than their daughters. Indeed, not a single parent reported that their daughters enjoyed greater mobility than their sons. Parents overwhelmingly reported that the gender differences inherent in restrictions on mobility were related to issues of safety, protection and reputation in the community.

When my son goes out, I am not worried about him. I know that he will be playing somewhere or sitting with his friends. But if my daughter doesn't come back home on time, then I get worried. (Urban mother, unmarried woman)

There are more restrictions for girls. But these restrictions are natural. Girls are like glass bangles. We are afraid. (Rural father, unmarried woman)

Similarly, the majority of parents who discussed the issue of social mixing of their sons and daughters reported that they restricted activities conducted with opposite-sex individuals.

If my daughter talks with girls, then there is no problem, but not with boys-that will not be allowed. (Urban mother, unmarried woman)

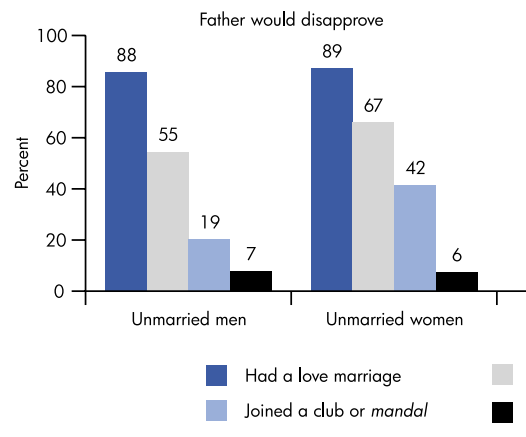

Young women were considerably more likely than young men to perceive parental disapproval of social activities. For instance, $67 \%$ of young women compared with $55 \%$ of young men reported expecting disapproval from their father if they talked with a person of the opposite sex from outside the home. Similarly, $42 \%$ of young women compared to $19 \%$ of young men
It looks bad to see a girl talking to a boy freely. [Laughing] If I had seen my daughter talking to a boy I would have slapped her and scolded her. What I say is for her good. (Rural father, married woman)

If my son had friendships with girls I would have warned him about it. (Rural father, married man)

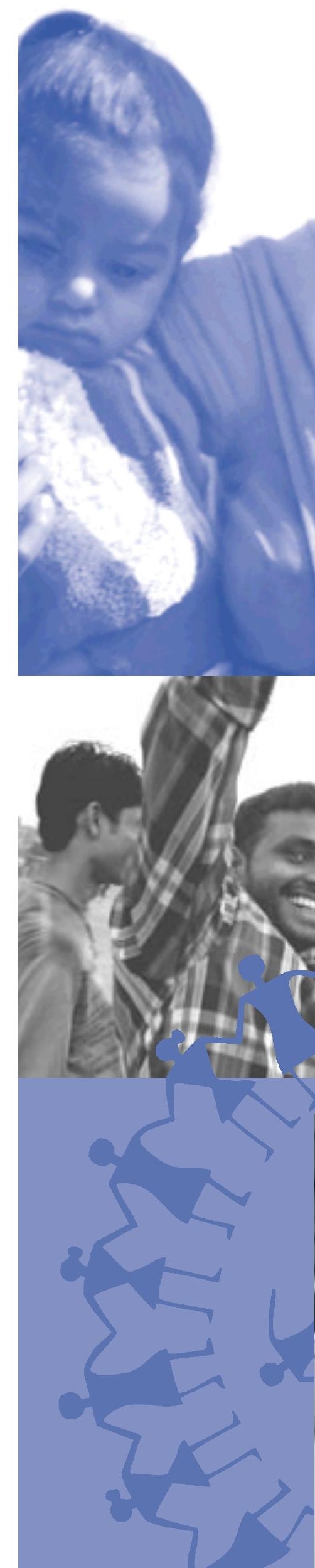


Communication with parents

Communication with parents on issues relevant to youth-including, for example, school performance, friendships, romantic relationships and reproductive processes-was far from universal. Moreover, sensitive topics—such as romantic relationships, reproduction and contraception, among all youth, and adolescent body change issues among young men-were rarely discussed with either parent (reported by $2-6 \%$ of youth). Nevertheless, among young women, mothers were reported as the most likely confidante on such matters as menstrual problems and experience of teasing (the latter not shown in the figure below), with $88 \%$ having discussed menstrual problems and 26\% having discussed experience of teasing.
Girls must not be given this information before marriage; they automatically come to know after marriage. (Rural mother, unmarried woman)

They [young people] watch movies and read books, so we need not tell them anything. (Urban mother, unmarried woman)

If my son asks me I don't have much knowledge on that to explain to him. (Urban mother, unmarried man)

Parental influences on young people's lives Findings indicate that parental factors-notably parental control and communication-did indeed influence the lives of young women and

Extent of communication with parents: percentage of youth reporting having discussed selected matters with parents

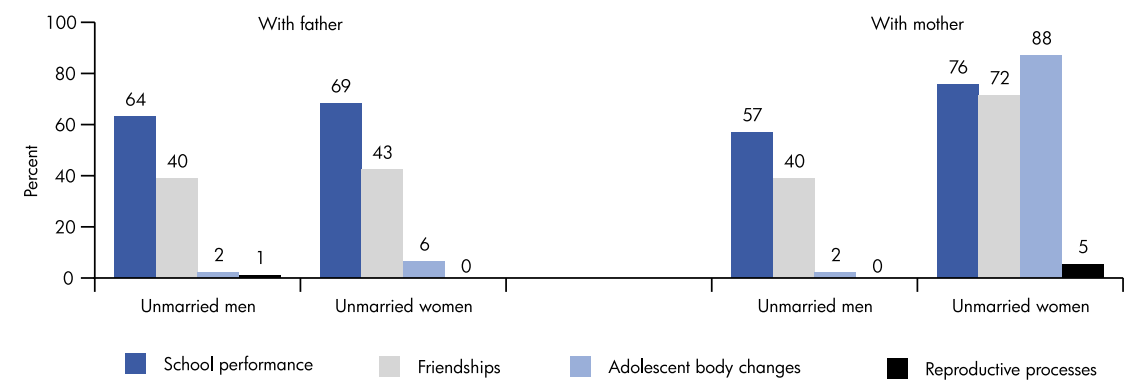

The majority of parents who were interviewed in-depth also reported that sexual and reproductive matters were rarely discussed with their adolescent daughters and sons. Parents cited several reasons for this lack of communication, including cultural taboos, perceptions that youth would have opportunities to gain such information on their own following marriage, availability of other sources including mass media and parents' own lack of knowledge of such matters.

They [young people] must discuss but not with their parents.... (Urban father, married woman) men in varied ways. They affected schooling patterns, participation in civil society, decisionmaking ability, self-efficacy, gender role attitudes and sexual behaviours.

Three major conclusions may be drawn. First, controlling parental behaviour ${ }^{1}$ clearly compromises youth development. Findings suggest that youth who reported parental control were less likely than others to have completed 12 or more years of education (among those aged 20 and above), to have participated in civil society activities, to display decision-making autonomy, ${ }^{2}$ mobility ${ }^{3}$ and self-efficacy ${ }^{4}$ and to express egalitarian gender role attitudes. ${ }^{5}$

${ }^{1}$ An index of parental control was calculated, taking into consideration young people's responses to questions on whether their parents would be angry if youth brought same-sex friends home, brought opposite-sex friends home, talked to an opposite-sex person from outside the home, went to a film, etc. with same-sex friends, went to a film, etc. with opposite-sex friends, joined a club/group, had a love marriage and found a job.

${ }^{2}$ An index of decision-making was created that considered young people's responses to questions related to their role in decisions regarding choice of friends, purchasing clothes and spending money.

${ }^{3}$ An index of mobility was created based on young people's responses to questions related to their freedom to visit a friend/relative within and outside the village/urban area, shop, health centre, place of entertainment, and programmes within and outside the village/urban area.

${ }^{4}$ An index of self-efficacy was created based on young people's responses to questions related to their ability to express their opinion to elders, and their ability to confront a person who says/does something wrong.

${ }_{5}^{5}$ The index of gender role attitudes took into consideration young people's responses to questions pertaining to whether they agreed or disagreed with the following statements: educating girls is as important as educating boys, husbands need not be the main decision-maker on money matters, girls should participate in marriage decisions, women do not need to take their husband's permission for any activity, girls' school performance is as good as that of boys, boys should do domestic work, and girls who dress provocatively do not deserve to be teased. 
